\title{
The nexus between sustainable livelihoods and ecological management of the World Heritage Sites: lessons from iSimangaliso World Heritage Park, South Africa.
}

\author{
A.T. Nzama' \\ Department of Recreation and Tourism, University of Zululand \\ atnzama@pan.uzulu.ac.za
}

\begin{abstract}
This paper explores the suitability of the ecological management approach to the management of the world heritage sites with an aim of linking sustainable livelihoods of local people and the protection of the resource. There are eight World Heritage Sites in South Africa; two of these, UKhahlamba Drakensberg and iSimangaliso Wetland Park are located in KwaZulu-Natal. The communities that live within and around these World Heritage Sites depend on the sites for their livelihoods through various tourism related activities. There is therefore a need for an approach that integrates biodiversity conservation with local and regional development which ensures sustainable livelihoods for local communities that depend on the resource for their survival. The objectives of the study were four-fold: (a) To explore the possibility of introducing and implementing ecological management at the world heritage sites, (b) To establish the local communities' understanding of the impacts of human-use on ecosystems and biological resources, (c) To assess the extent to which local communities are involved in biodiversity conservation programmes and (d) To find out if the programmes currently in place are directed at integrating social, economic and environmental issues of the study area. The findings of this study indicate that people living inside and on the buffer of iSimangaliso Wetland Park are aware of the activities that may lead to the degradation of the ecosystems. They are also willing to learn more about the ways in which the resource can be optimally used for their economic survival but at the same time protected from overuse. The findings of the study further indicate that with the common understanding between the site authorities and local communities it is possible that ecological management can be introduced and implemented within the World Heritage Sites.
\end{abstract}

Keywords: Sustainable livelihood; ecological management; world heritage sites; iSimangaliso world Heritage Park; South Africa

\section{Introduction}

Ecological management is one of the approaches that has been seen to have a potential of linking nature conservation and people's livelihood to a point where there is a symbiotic relationship between the two. Ecological management refers to the management of human activities so that ecosystems, their structures, function, composition and the physical, chemical and biological processes that shape them, continue at appropriate temporal and spatial scales. This approach is sometimes referred to as ecosystem management or an ecological approach to management. The implementation of the ecological management approach requires the involvement of all stakeholders to ensure that they understand the status of the species and genetic composition of the resources in ecosystem. It is therefore important to develop comprehensive and detailed inventories of the biodiversity found within each ecosystem and to establish its capacity to withstand utilisation for the sustenance of livelihoods of the local communities.

This paper explores the suitability of the ecological management approach to the management of the world heritage sites with an aim of linking sustainable livelihoods of local people and the protection of the resource using Isimangaliso Wetland Park as a case study. The world heritage sites are in most cases seen as tourism resources and yet by their nature, these sites are sensitive environments that need protection from any form of degradation. Tourism has proved to have a potential to positively contribute to socio-economic and cultural environments, but at the same time it may cause degradation of the environment and loss of local identity (Wanhove, in Pigram and Wahab, 2004).

In KwaZulu-Natal there are two World Heritage sites, uKhahlamba Drakensberg and Isimangaliso Wetland Park. ISimangaliso Wetland Park was the first site in South Africa to receive the World heritage status in 1999 based on three main characteristics (I) its unique ecological processes, (2) its superlative natural phenomenon and (3) its exceptionally rich biodiversity (Mkhize, 2007). Due to its world heritage status, iSimangaliso has become one of prime tourism destinations in KwaZulu-Natal. With an increase in the number of tourists who have diverse consumption patterns, iSimangaliso Park Authorities had to explore sustainable approaches to resource management that would address social justice issues while meeting nature conservation objectives of the country. This assertion highlights the need for an approach that integrates biodiversity conservation with regional development which ensures sustainable livelihoods for local communities that depend on the resource for their survival. It is, after all, incumbent upon the authorities to orient tourism growth towards meeting its conservation and socio-economic objectives (Pigram and Wahab, 2004).

I. Thandi Nzama, PhD, is a Senior Lecturer and Head of the Department of Recreation and Tourism, University of Zululand, South Africa 


\section{Background to the study}

One of the focal points of this paper is to explore the potential of the ecological management approach in forging a symbiotic relationship between conservation of ecosystems and sustainable livelihoods of local communities. In South Africa, generally, and specifically iSimangaliso Wetland Park, ecotourism and conservation are deemed as regional drivers for economic development and poverty alleviation (Zalomous, 2007, 2008). This pronouncement implies that iSimangaliso Wetland Authority has to align itself with the shift in national priorities from a strong focus on conservation to a new approach that integrates biodiversity conservation with regional development. This shift also necessitates that opportunities and policies have to be created to support sustainable tourism development that encourage new uses of the biodiversity that might provide new diversification and investment which would contribute to the improvement of the lives of the local communities.

In line with the democratic changes in the country, the tourism and conservation policy framework has brought positive changes to the South African tourism landscape. Rogerson \& Visser (2004) argue that these changes necessitated the integration of all activities by government, the private sector and the individual members of the local communities that are aimed at promoting sustainable tourism development. While the government is mainly responsible for developing policies that support tourism development, local communities are expected to participate actively in conservation as well as in tourism development and also to take advantage of the entrepreneurial opportunities created by the private sector (Rogerson \& Visser, 2004).

Many communities and individuals have a wealth of knowledge that is relevant to the conservation and diversity and the sustainable use of biological resources. This knowledge may relate to harvesting resources, plant crops, and using natural herbs and other materials for medicinal purposes etc. Traditional knowledge can provide an excellent basis for developing programmes and policies that integrate social, economic and environmental issues and which would benefit both the environment and the local communities.

Isimangaliso Wetland Park stretches northwards from Mapelane Nature Reserve and incorporates St Lucia Game and Marine Reserves, False Bay Park, Cape Vidal, Sodwana Bay, Mkuze Game Reserve and the Maputaland Marine Reserve covering 230000 hactares. Four sites of the iSimangaliso Wetland Park are registered as wetlands of international significance under the Ramsar Convention. Besides the unique $38000 \mathrm{ha}$ expanse of St Lucia Lake, islands and the estuary, the iSimangaliso Wetland Park incorporates a variety of ecosystems ranging from the Lebombo mountain ranges to grasslands, forests, wetlands, mangroves, dune forests, massive stretches (nearly $200 \mathrm{~km}$ ) of unbroken white beaches and off-shore coral reefs as well as the largest estuary in Africa (refer to Figure I).

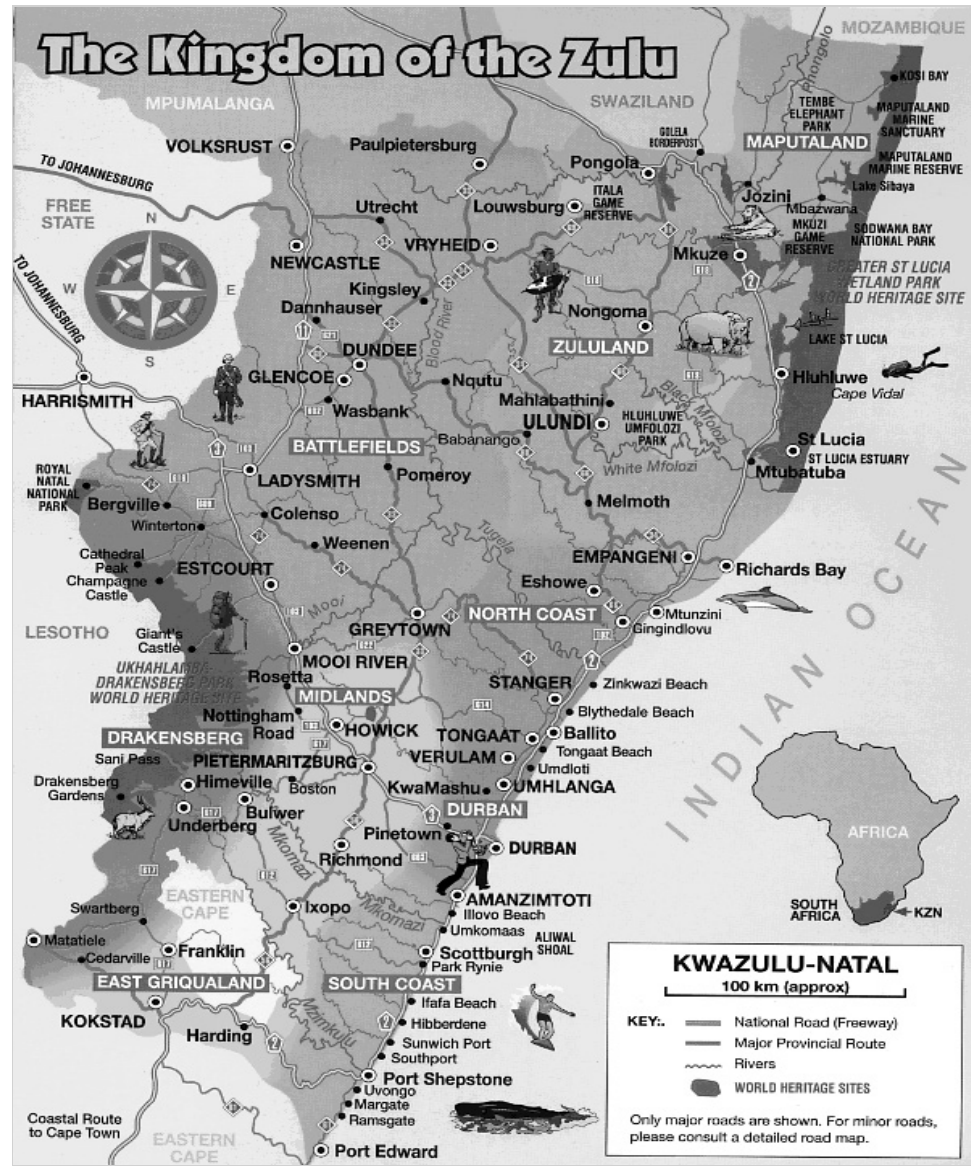

Local people depend on this resource for their livelihood and therefore there is perpetual conflict between users and the custodians of the park. All these various ecosystems have to managed such that there is optimal benefit for local communities who depend of the land for subsistence and at the same time making sure that the resources id protected from degradation. The main threats as identified by the Wetland authority include (a) land claims (b) the prevalence of evasive alien plants (c) large scale commercial afforestation in endemic grassland and water catchment (d) land use and land tenure (e)degradation due to the closure of the mouth of the St Lucia estuary.

Figure 1 The location of the study area, the iSimangaliso wetland park world heritage site

Source: Tourism KwaZulu-Natal (2005) 
An increase in the number of tourists not only heightened the expectations of the local communities to reap benefit that accrue from tourism development but also necessitated stringent management strategies that would ensure that the ecological integrity of iSimangaliso Wetland Park is protected from degradation.

\section{Objectives}

There are many interesting aspects of the iSimangaliso Wetland Park that need to be understood as source for sustainable development, however, for the purpose of this paper some objectives are put forwards to make them stand out as the broad intention of the paper. The objectives of the paper are four-fold:

- To explore the possibility of introducing and implementing ecological management at the world heritage sites.

- To establish the local communities' understanding of the impacts of human-use on ecosystems and biological resources.

- To assess the extent to which local communities are involved in biodiversity conservation programmes.

- To find out if the programmes currently in place are directed at integrating social, economic and environmental issues of the study area.

\section{Theoretical framework}

Studies have indicated that an increase in the number of tourists is accompanied by an increase in the consumption of the biodiversity and negative impacts on the form and structure of natural as well as socio-cultural environments of the local communities are inevitable (Dowling \& Page, 2002; Hunter \& Green, 1997; Perrow \& Davy, 2002; Pigram \& Wahab, 2004). This means that since iSimangaliso Wetland Park has become a prime tourist destination changes in the natural environment mainly the structure and form of ecosystems are inevitable if there is no proper management of the resources and users. The users include both local people who use the resource as a source of their livelihood e.g fishing, creating products for tourists such art and craft using local grass and wood and the tourists who use the resource to derive quality experiences (Zalomous, 2007, 2008). The real challenge is to manage the risk to biodiversity posed by community encroachment on the park and overuse by the tourists. Ecotourism management is, therefore one of the approaches that can be used to address this challenge.

The conflict between tourism and protection of the biodiversity has a long history stretching back from the 1960s when it became clear that the natural environment is an exhaustible resource (Bosselman, 1978; Dowling \& Page, 2002; Farrell \& McLellan, 1987; Holden 2000; Pearce, 1985; Young, 1985;). In most cases this conflict indicates inequality in the ownership, management and the flow of benefits from use and conservation of resources (Furze, de Lacy \& Birckhead, 1997). Gunn (1978) maintains that the demand for tourism rather than cause conflict with conservation, requires the tourist attraction to a destination should not be degraded.

In the case of iSimangaliso, the main attraction is the quality of resource itself which led to it receiving the world heritage status. iSimangaliso Wetland Park like many other protected areas has a dual mandate of being the protector and conserver of biodiversity and of acting as a catalyst for local and regional tourism development. Managers of such protected areas find themselves faced with a dilemma because they have to execute both the protective and the economic development functions (Furze, de Lacy \& Birckhead, 1997).

Ideally, tourism development and ecological sustainability should be complementary and mutually reinforcing (Pigram \& Wahab, 2004). WRI et al (in (Furze, de Lacy \& Birckhead, 1997: 2I) identifies six fundamental causes of biodiversity loss. These are (a) the unsustainably high rate of human population growth and natural resource consumption (b) the steadily narrowing spectrum of traded products (c) economic systems that fail to value the environment and its resources; (d) inequity in the ownership, management and flow of benefits from both use and conservation of biological resources; (e) deficiencies in knowledge and its application and (f) the legal institutional systems that promote nonsustainability. Some of these causes apply to the study area. As an example the South African Tourism Growth Strategy is founded upon five objectives:

- To increase tourism volume at high and sustainable rates.

- To increase the total spending by tourists in South Africa.

- To optimise the length of stay in order to maximise revenue yield.

- To improve the volume of spending and distribution of revenue throughout the year.

- To improve activity and spending patterns to enable transformation and promote black economic empowerment.

Consumption of these resources would of course be good news for local communities but may be detrimental to the conservation of biodiversity.

Furze, de Lacy \& Birckhead (1997: 28) summarise the threats to protected area as follows: (a) conflict with local people (b) lack of policy commitment at national and provincial levels to adequately protect the systems (c) ineffective management by trained staff of individual protected areas (d) insufficient funding and (e) inadequate public support. In the 
case of ISimangaliso Wetland Park it is the commitment of the national government to conservation issues that led to the conflict with local small business owners.

The concerns of the local business community therefore required creativity on both the government and the local communities that would forge a symbiotic relationship between nature conservation and tourism development. Pigram \& Wahab (2004) maintain that a key to tourism success is the ability and willingness of the stakeholders to recognize the change and use it to their advantage for long term sustainable growth. The government had to come up with policies that would protect the environment and simultaneously encourage sustainable and responsible tourism development. Local residents and business people living in and around iSimangaliso Wetland Park questioned sustainability in the face of their collapsing businesses which translated to the elimination of the two major benefits of tourism which, according to Vanhove (2004), are income creation and generation of much needed jobs.

Pigram \& Wahab (2004) maintain that while natural attributes form distinctive advantages for developing nations, the use of human intelligence and creativity can make the difference. Creativity comes into play when new approaches have to be followed in an attempt to adapt businesses to the environment. Environmental adaptability is seen by many as a means of economic competition (Aronsson, 2000). Faced with these changes it is important to adapt to the new circumstances and find ways that would lead to new uses of biological resources and identify new opportunities which might serve as incentives private landowners and other stakeholders to become involved in biodiversity related programmes as well as identify areas where new uses of biological resources may provide the basis for further economic diversification that would allow them to compete favourably within the tourism industry.

\section{Methodology}

With a view of addressing the main objectives of the study, a random sample of 226 respondents was drawn from the study area. The sample consisted of officials from Ezemvelo KZN Wildlife, the custodian of the iSimangaliso Wetland Park, and local community members that live within and around the Park. Person to person interviews were conducted on selected days using structured questionnaires. The distribution of the respondents was as follows:

\section{Sample distribution of respondents}

\begin{tabular}{|l|c|c|}
\hline \multicolumn{1}{|c|}{ Respondents } & Freq & Freq \% \\
\hline Ezemvelo KZN Officials & 28 & 14 \\
\hline Local community members & 198 & 86 \\
\hline Total & 226 & 100 \\
\hline
\end{tabular}

\section{Analysis and findings}

The questions that were asked revolved mainly around three issues (a) local communities understand the impacts of human-use on ecosystems and biological resources (b) the possibility of introducing and implementing ecological management at iSimangaliso Wetland Park (c) the extent to which local communities are involved in biodiversity conservation programmes, and (d) whether the programmes currently in place integrate social, economic and environmental issues of the study area.

\subsection{Impacts of human-use on ecosystems and biological resources}

In an attempt to enhance a balance between maximising the sustainable use of the environment and protection thereof, it is imperative that local people understand the impacts of human use and issues that relate to the relationship between the protection of the biological diversity, tourism development and management within the park [Refer to Table I]. Local people should understand the significance of promoting the sustainable forms of tourism that have the capacity of integrating nature conservation and sustainable livelihoods for all communities living within and around iSimangaliso World Heritage Park (Pigram and Wahab, 2004). The respondents were asked to express their opinions based on their understanding of the impacts of human use on the ecosystem.

The findings indicated that the majority of the people who live and work at iSimangaliso Wetland Park, Ezemvelo KZN Wildlife Officials and local community members have a good understanding of environmental issues as well as the impacts of human use on biodiversity. The latter is reflected in the scores shown in Table I, with an average $69 \%$ for officials and $51 \%$ for the local community. These responses indicate that people living inside and on the buffer of the iSimangaliso Wetland Park are aware of the activities that may lead to the degradation of the ecosystem which they need for their own survival. These responses indicate that people living inside and on the buffer of iSimangaliso Wetland Park are aware of the activities that may lead to the degradation of the ecosystems. They are also willing to learn more about the ways in which the resource can be optimally used for their economic survival but at the same time protected from overuse.

Inkanyiso, Jnl Hum \& Soc Sci 2009, I(I) 
Table I Impacts of human use on the biodiversity [\%]

\begin{tabular}{|l|c|c|}
\hline \multicolumn{1}{|c|}{ Statements } & \multicolumn{1}{c|}{$\begin{array}{c}\text { Ezemvelo KZN } \\
\text { wildlife officials }\end{array}$} & $\begin{array}{c}\text { Local community } \\
\text { members }\end{array}$ \\
\hline Protecting the ecosystem is everybody's responsibility & $62 \%$ & $58 \%$ \\
\hline There should be more education and training programmes about the ecosystems & $65 \%$ & $54 \%$ \\
\hline There should be a limit to the harvesting of resources & $74 \%$ & $53 \%$ \\
\hline Harvesting periods should be specified and adhered to & $68 \%$ & $63 \%$ \\
\hline Alien evasive plants should be removed & $82 \%$ & $62 \%$ \\
\hline Cultivation should be done in ways that do not dehydrate the wetland & $67 \%$ & $61 \%$ \\
\hline Care should be taken of sand dune stabilization & $68 \%$ & $48 \%$ \\
\hline Degraded habitats should be rehabilitated & $61 \%$ & $47 \%$ \\
\hline Cultural heritage should be protected & $73 \%$ & $68 \%$ \\
\hline
\end{tabular}

To reduce the impact of human use on the ecosystem, the government introduced legislation which led to the banning of the use of $4 \times 4$ recreational vehicles at the beach in the study area. The respondents were asked to respond to the question of whether there were any observable signs of environmental recovery since the banning of the $4 \times 4$ recreational vehicles at the beach in December 2004. The responses of the two groups of respondents indicated that, even though they live and work at the same area, their observations are quite different [Refer to Figure 2].

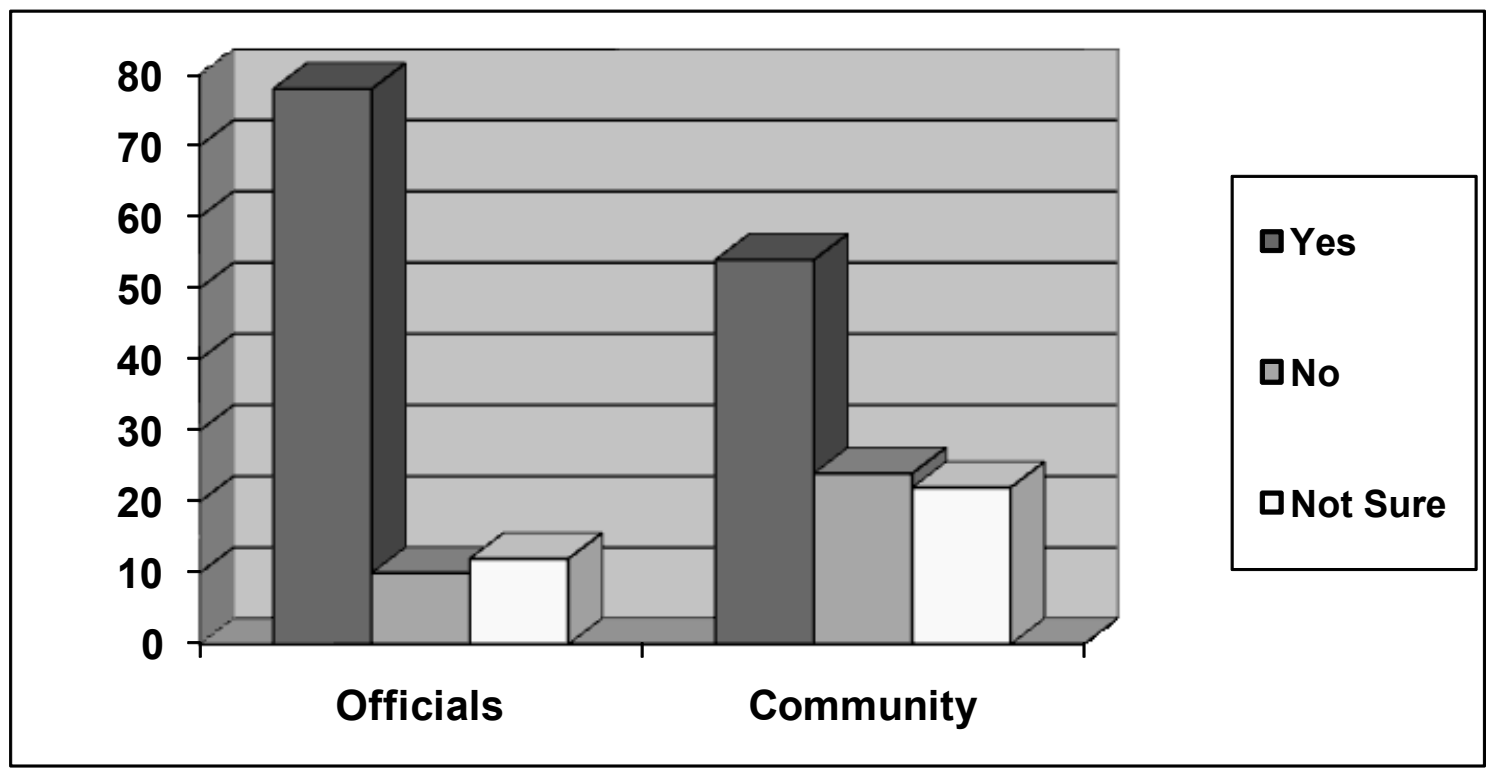

Figure 2 Responses on the observable signs of environmental recovery

The KZN Ezemvelo officials [78\%] mainly those who have worked in the same area for a long time and have had an opportunity to observe the natural environment before and after the $4 \times 4$ vehicle ban regulations were implemented expressed themselves as follows:

- The ecosystem has recovered and blossomed;

- There are more loggerhead and leatherback turtles;

- More crabs can now be observed crawling at the beach;

- Species that breed at the beach are more protected;

- Plants along the beach show signs of recovery;

- Observable sand dune stabilization; and

- Beach users are no longer interrupted by vehicles. 
Responding to the question of whether the $4 \times 4$ vehicle ban regulation be upheld or not, the majority of the local community members $(62 \%)$ indicated that the regulation should not be upheld mainly due to economic reasons, while the majority of the KZN Ezemvelo officials $(56 \%)$ felt that it should be upheld so as to protect the ecological integrity of the park.

Table 2 The necessity to uphold the $4 \times 4$ vehicle ban

\begin{tabular}{|l|c|c|}
\hline \multicolumn{1}{|c|}{ Responses } & KZN Ezemvelo Officials & Local Community Members \\
\hline Yes & $56 \%$ & $24 \%$ \\
\hline No & $35 \%$ & $62 \%$ \\
\hline Not sure & $09 \%$ & $14 \%$ \\
\hline Total & $100 \%$ & $100 \%$ \\
\hline
\end{tabular}

The reasons that were advanced by those who felt that the regulation should be upheld include the following:

- The natural environment should be protected for iSimangaliso Wetland Park to maintain its world heritage status;

- The removal of $4 X 4$ vehicles from the beach will promote new forms of tourism such as ecotourism;

- New forms of tourism will open new domestic and international markets; and

- New types of tourists will demand new forms of products.

The reasons that were given by those who felt that the regulation should not be upheld include the following:

- The regulation reduces the number of tourists who stay longer and buy in bulk from local businesses;

- There are other ways of protecting the turtles and the crabs such as putting the tape around sensitive areas such as those where there are eggs of turtles;

- The regulation is too drastic and robs local people of their livelihood;

- Destruction of the socio-economic environment;

- Destabilisation of the local communities;

- Closure of some businesses;

- Increase in the crime rate; and

- Increase in poverty.

From these analyses it could concluded that local community members, whose livelihood is dependant on the use of the resources, would like to see the banning of the $4 \times 4$ regulation upheld.

6.2 The introduction and implementation of ecological management.

The implementation of ecological management approach requires integrated planning that involves local communities. Integrated planning should incorporate ecological, social, cultural and economic objectives and accommodate public and stakeholder participation to prevent and resolve conflicts among various resources users (Wahab \& Pigram, 2004). Integrated planning processes can be applied in several ecosystems by providing opportunities for multi-stakeholder participation to determine resource use and conservation approaches. The activities currently observable at iSimangaliso Wetland Park indicate that Park Authorities are striving to put in place the mechanisms that could lay a foundation for the introduction of the ecological management approach. In this regard respondents were asked to indicate their involvement in conservation and tourism planning and development processes.

Table 3 Community's understanding of ecological management processes

\begin{tabular}{|l|c|c|c|}
\hline \multicolumn{1}{|c|}{ Statements } & Yes & No & No Sure \\
\hline All human activities should be managed & $52 \%$ & $26 \%$ & $22 \%$ \\
\hline Tourism related activities should be controlled and monitored & $38 \%$ & $43 \%$ & $19 \%$ \\
\hline The integrity of ecosystems should be maintained & $57 \%$ & $39 \%$ & $04 \%$ \\
\hline Use and consumption of the resources should be balanced & $56 \%$ & $28 \%$ & $16 \%$ \\
\hline
\end{tabular}

iSimangaliso Wetland Park authorities have continually attempted to involve local communities in the biodiversity management processes. The results reflected in Table 3 are an indication that local communities have embraced the notion of ecosystem protection and management. The majority of the local communities reflect an understanding of ecological management of the study area. Based on these finding it may be concluded that the iSimangaliso Wetland Park authorities can have the support of the local community to introduce and implement the ecological management Inkanyiso, Jnl Hum \& Soc Sci 2009, I(I) 
approach in the study area. The findings in Table 3 therefore indicate that iSimangaliso Wetland Park has adapted its management activities and thus it is amenable to the use of the ecological management approach

\subsection{Involvement of communities in biodiversity related programmes}

The successful implementation of the ecological management approach requires the involvement of the local communities to ensure that there is a link between nature conservation and people's livelihood. World Heritage sites such as iSimangaliso Wetland Park need to empower local communities to progressively share in the responsibility of managing the biodiversity of the site. The government imperative for these sites is that there should be broad participation of local communities in management, sharing of economic benefits and conflict resolution mechanisms (Rogerson \& Visser, 2004). As shown in Table 4, local communities showed some level of reluctance to participate fully in biodiversity related programmes in the study area.

Table 4 Community involvement in tourism planning and development processes

\begin{tabular}{|l|c|c|c|}
\hline \multicolumn{1}{|c|}{ Statements } & Yes & No & No Sure \\
\hline Involvement in planning and development & $48 \%$ & $42 \%$ & $10 \%$ \\
\hline Participation in tourism planning and development & $45 \%$ & $37 \%$ & $18 \%$ \\
\hline Attendance of environmental awareness workshops & $42 \%$ & $37 \%$ & $21 \%$ \\
\hline Attendance of training sessions on ecological management & $33 \%$ & $43 \%$ & $24 \%$ \\
\hline
\end{tabular}

The emerging conclusions reflect that despite the fact that regular outreach workshops are held to foster communication between iSimangaliso Wetland Park and the communities, participation in planning and development activities is still limited. This reluctance can be ameliorated by the introduction of incentives that would motivate the community to engage in activities that lead to conservation and sustainable use of the resources. It is also worth mentioning that the iSimangaliso Wetland Park authorities have taken strides to involve local communities in the planning and development of conservation and tourism activities in the park. There are various programmes that are run by the Parks' Authority in partnership with the local communities and the private sector (Zaloumis, 2007, 2008). These programmes are aimed at enhancing the local communities' understanding of the ecosystems and enable them to determine the impacts of human use of resources on biodiversity.

With regard to community involvement in tourism planning and development, it is evident that there is still a need for more awareness programmes aimed at reaching out to those local community members who are still operating at the periphery of the biodiversity discussion platform. Engaging and educating as many people as possible is imperative to achieving a broad based participation of local communities in the protection and management of the world heritage resource. The Park authorities have also created opportunities that allow community members to participate in activities that are aimed at enhancing their understanding of functioning of the ecosystem such as the community based natural resource harvesting programme; removal of invasive alien plants programme, projects on planting of indigenous trees, etc. This understanding has led to entrepreneurship creativity and innovation in terms of creating a variety of ecoproducts most of which make use of the resources that are harvested within the park.

\subsection{The integration of socio-economic and environmental issues}

Ecological management approach encourages the integration of socio-economic and environmental planning of the utilisation of cultural and natural resources. On being asked, the majority [58\%] of the respondents indicated that they were aware of various programmes that integrate social, economic and environmental issues of iSimangaliso. The respondents [55\%] further indicated their awareness of the programmes that focus on creating job opportunities through infrastructural development and on capacity building. These programmes are aimed at empowering local communities through specialised training and equity partnerships in tourism development.

Some of the respondents [38\%] attested that new entrants in the small business sectors are provided with training and mentoring to ensure the sustainability of their businesses. In addressing historically sensitive social issues, such forced removal and land claims, both local communities [52\%] and park authorities [58\%] indicated that most of the land claims which presented a challenge to sustainable development of the park have since been settled. Capacity building programmes were provided in order to introduce the land claimants to the sustainable forms of resource use and management. ISimangaliso also hosts mobile outreach workshops with key community partners, as part of its "people and parks programme" to enhance communication with the local communities within and on the buffer zone of the park (Isimangaliso News, August - October 2008) 


\section{Conclusions and recommendations}

The findings of this study have indicated the significance of the symbiotic relation between the sustainable use of natural resources and the protection thereof. Integrated planning should form the basis for the implementation of the ecological management approach and enhance the effectiveness of environmental assessments. These assessments are useful in determining any adverse impacts of economic developments on the ecosystem, species and genetic resources and to recommend appropriate mitigation measures. Ecological management ensures that communities such as those living inside and around iSimangaliso Wetland Park which depend mainly on tourism for their survival participate in discussions that will enhance their understanding of the nature and structure of the ecosystems that support their livelihoods.

Finally, it is important to state that the fundamental objectives of this study relating to: relating to: (a) local community's understanding of the impacts of human-use on ecosystems and biological resources; (b) the introduction and implementation of ecological management systems; (c) the local community's involvement in biodiversity and conservation programmes, and (d) the integration of socio-economic and environmental problems, have been thoroughly addressed.

Based on the objectives of this study the following recommendations were made.

- The ecological management approach should be considered for implementation at all world heritage sites because of its capacity to integrate social, economic and environmental imperatives of the resource, and

- World heritage sites authorities should articulate the ways by which local communities would be encouraged to participate fully in activities and programmes that would enhance their understanding of the nature and structure of the ecosystems of the site.

\section{References}

Aronsson, A. (2000). The development of sustainable tourism. New York: Bath Press.

Binns, T. \& Nel, E. (2002). Tourism as a local development strategy. South African Geographical Journal, Vol. I68 (44-67).

Bosselman, F. (1978). In the wake of the tourist; managing special places in eight countries. Washington; The Conservation Foundation.

Cohen, E. (1978). The impact of tourism on the physical environment. Annals of Tourism Research. Vol 5 (2) 87-94.

DACT [Department of Arts, Culture and Tourism] (2006). KwaZulu-Natal. Strategic Plan 2005 - 2010. Pietermaritzburg. DACT.

DEAT [Department of Environmental Affairs and Tourism] (1996). White Paper on the Development and Promotion of Tourism in South Africa. Pretoria: DEAT, Government Printers.

DEAT [Department of Environmental Affairs and Tourism] (1997). Tourism Development Strategy 1998-2000. Pretoria: DEAT, Government Printers.

DEAT. [Department of Environmental Affairs and Tourism] (1999). Institutional Guidelines for Public Sector. Tourism Development and Promotion in South African. Pretoria: DEAT, Government Printers.

DEAT [Department of Environmental Affairs and Tourism] (2002). Handbook: Support Programmes for Tourism Businesses. Pretoria: DEAT, Government Printers.

DEAT [Department of Environmental Affairs and Tourism] (2003a). Tourism 10-year Review. Pretoria: DEAT, Government Printers.

DEAT [Department of Environmental Affairs and Tourism] (2004). South African Tourism Growth Strategy 2004 to 2007. Pretoria: DEAT, Government Printers.

DEAT [Department of Environmental Affairs and Tourism] (2007). South African Tourism - Global Competitiveness Programme for the Tourism Industry in South Africa. Pretoria: DEAT, Government Printers.

DEAT [Department of Environmental Affairs and Tourism] 2004. South African Tourism. Business Tourism Growth Strategy (2008-2010). Pretoria: DEAT, Government Printers.

Dowling, R. K. (1993). An environmentally based planning model for regional tourism development. Journal of Sustainable Development Vol. I (I): 17-37.

Dowling, R. K. \& Page, S. J. (2002). Ecotourism. New York: Prentice Hall Publishers.

Farrell, B \& McLellan, R. (1987). Tourism and physical environment research. Annals of Tourism Research Vol. I4 (I): I-I6.

Farrell, B. \& Runyan, D. (1997). Ecology and Tourism. Annals of Tourism Research. Vol. I8 (I): 4I-56.

Furze, B., De Lacy, T. \& Birckhead, M. (1997). Culture, Conservation and Biodiversity. The Social Dimension of Linking Local level development and conservation through protected areas. Chishester: John Wiley \& Sons.

Gunn, C. (1978). Needed: An international alliance for tourism-recreation-conservation. Travel Research Journal. Vol 2 (3) 3-9.

Holden, A. (2000). Environment and Tourism. London: Routeledge.

Hunter, C. \& Green, H.. (1995). Tourism and the environment: A sustainable relationship? London: Routlegde..

Hunter, C. \& Green, H. (1997). Tourism and the Environment: A sustainable relationship. London: Routledge.

Kesper, A. (200I). Failing or not aiming to grow? Manufacturing SMME, and their contribution to employment growth in SA. Urban Forum, 12.

Knight, R. (200I). Shared Interest. South Africa: Economic Policy and Development. www.Richardknight.homestead.com/files/ sisa economy. htm.

Kirsten, M. \& Rogerson, C. M. (2002). Tourism Business linkages and small enterprises development in South Africa. Development Southern Africa, 19, I.

Lewis, J. D. (200I). Policies to Promote Growth and Employment in South Africa. Washington DC.: World Bank.

Inkanyiso, Jnl Hum \& Soc Sci 2009, I(I) 
Mkhize, K. (November 2007 - January 2008). Isimangaliso News, 2007 Vol I.(I).

Page, S. J., Brunt, P., Busby, G. \& Connell, J. (200I). Tourism: A modern synthesis. London: Thomson Learning.

Pearce, D. G. (1985). Tourism and Environmental Research: a review. International Journal of Environmental Studies, 25 (4): 247 255.

Perrow, M. R. \& Davy, A. J. (2002). Handbook of Ecological Restoration. Volume I Principles of restoration. New York: Cambridge University Press.

Pigram, J. J. \& Wahab, S. (ed) (2004). Tourism Development and Growth : the challenge of sustainability. New York: Routledge.

Rogerson, C. M. \& Visser, G (2004). Tourism and Development in Post- Apartheid South Africa. A Ten-Year Review. In Rogerson, C. M. and Visser, G. (Ed.), (2004) Tourism Development issues in contemporary South Africa. Africa Institute of South Africa. Pretoria.

SAT [South African Tourism] (2004a). Gearing up to be globally competitive: Tourism Growth Strategy 2008-2010. Pretoria. South African Tourism

The Cluster Consortium. (1999). The SA Tourism Cluster Strategy in Action. Unpublished Report Prepared for the Tourism Cluster Initiative. Johannesburg: Cluster Consortium.

TBCSA [Tourism Business Council of SA] (2002). South African Tourism Industry: Empowerment and Transformation. Annual Review.

TKZN [Tourism KwaZulu-Natal] (2005). What, Where, and When magazine. Durban: Tourism KwaZulu-Natal.

Vanhove, N. (2004). Mass Tourism : Benefits and Costs. In Pigram, J. J and Wahab, S. (Ed) (2004): Tourism Development and Growth: The challenge of sustainability. New York: Routledge.

Weeks, J. (1999). Stuck in Low GEAR? Macroeconomic policy in South Africa, 1996-1998. The Cambridge Journal of Economics, 23, 6, 759-8II.

Young, G. (1973). Tourism: Blessing or Blight. Harmondsworth: Penguin Publishers.

Young, B. (1985) Tourism and Conservation Workshop. Journal of Rural Studies, Vol. I (I): 97- 100.

Zaloumis, A. (November 2007 - January 2008). Inside Track. iSimangaliso News, I, I. 